\title{
Komunikasi Pemerintah Daerah Kabupaten Lombok Utara dalam Pemulihan Pembangunan Ekonomi Pasca Gempa
}

\author{
Hartin Nur Khusnia ${ }^{1}$, Muhlis ${ }^{2}$, Siti Chotijah ${ }^{3}$, Yulanda Trisula Sidarta Yohanes ${ }^{4}$ \\ 1,2,3,4 Universitas Mataram, Indonesia \\ Contact: hartinnkhusia@gmail.com
}

\begin{abstract}
North Lombok Regency is an area that was significantly affected by the earthquake. The recovery of economic development after the earthquake in North Lombok focuses on the aspects of economic support infrastructure development and systems that support the acceleration of economic development, both in the fields of tourism, MSMEs, agriculture, and plantations, including in the social life of the community. However, in its implementation, there are communication barriers between related agencies. The emergence of sectoral egos that is more dominant in organizational communication practices in the regional government of North Lombok Regency is predicted to be an obstacle to the acceleration of economic development in the North Lombok district. This is because the implementation of the post-earthquake economic recovery program requires cooperation between regional work units within the North Lombok Regency government. Therefore, it requires effective coordination between work units of the regions so that the implementation and objectives of the programs that have been formulated can take place optimally. This study uses a qualitative descriptive method, where data is obtained through in-depth interviews, observation, and documentation. The research data was obtained from informants, namely policymakers in related agencies.
\end{abstract}

Keywords: Government communication, development recovery, local government

\begin{abstract}
ABSTRAK
Kabupaten Lombok Utara merupakan wilayah yang terdampak bencana gempa bumi secara signifikan. Pemulihan pembangunan ekonomi pasca gempa bumi di Lombok Utara fokus pada aspek pembangunan infrastruktur penunjang ekonomi dan sistem yang mendukung percepatan pembangunan ekonomi, baik dalam bidang pariwisata, UMKM, pertanian dan perkebunan, termasuk dalam kehidupan sosial masyarakat. Namun, dalam pelaksanaannya terdapat hambatan komunikasi antar dinas terkait. Munculnya ego sektoral yang lebih mendominasi dalam praktik komunikasi organisasi di pemerintah daerah kabupaten Lombok utara diprediksi akan menjadi penghambat percepatan pembangunan ekonomi di kabupaten Lombok Utara. Sebab, pelaksanaan program pemulihan ekonomi pasca gempa bumi memerlukan kerjasama antar satuan kerja perangkat daerah di lingkungan pemerintah Kabupaten Lombok Utara. Oleh karena itu, dibutuhkan koordinasi yang efektif antar satuan kerja perangkat daerah sehingga pelaksanaan dan tujuan program yang telah dirumuskan dapat berlangsung optimal. Penelitian ini menggunakan metode deskriptif kualitatif, dimana data diperoleh melalui wawancara mendalam (Indepth Interview), pengamatan (observasi) dan dokumentasi. Data penelitian diperoleh dari informan, yaitu para pengambil kebijakan di dinasdinas terkait.
\end{abstract}

Kata Kunci : Komunikasi pemerintahan, pemulihan pembangunan, pemerintah daerah

\section{Pendahuluan}

Kabupaten Lombok Utara adalah salah satu dari sepuluh Kabupaten/Kota di wilayah Nusa Tenggara Barat. Menjadi kabupaten termuda membuat Pemerintah Daerah Lombok Utara harus bekerja keras untuk meningkatkan pembangunan di segala bidang, termasuk percepatan pembangunan ekonomi. Secara khusus Pemerintah Daerah Kabupaten Lombok 
Utara mencanangkan program Pemberdayaan Ekonomi dan Penanggulangan Kemiskinan (Pemberdayaan Ekonomi Dari Desa) sebagai upaya percepatan pembangunan ekonomi. Hasil yang diharapkan dari program ini adalah tersusunnya design dan pilot project inovasi penanganan kemiskinan secara terpadu berbasis kawasan; Tersusunnya design inovasi pemberdayaan ekonomi desa melalui penguatan Bumdes; Tersedianya inovasi pengembangan Desa Ekowisata berbasis masyarakat; Tersedianya design inovasi pembangunan pertanian yang men-supply kebutuhan pariwisata dan peningkatan produksi pertanian pada lahan kering; Tersedianya design industrialisasi/pengolahan hasil pertanian.

Peristiwa gempa bumi pada Agustus 2018 yang melanda Nusa Tenggara Barat, dan berdampak secara signifikan di Kabupaten Lombok Utara membuat pemerintah daerah harus bekerja ekstra untuk memulai kembali dari awal program percepatan pembangunan ekonomi yang telah dicanangkan sejak tahun 2016 lalu. Sebagaimana dilansir dalam situs BNPB "Kedeputian Rehabilitasi dan Rekonstruksi BNPB terus melakukan perhitungan kerusakan dan kerugian akibat gempabumi di NTB, baik gempa 6,4 SR pada $29 / 7 / 2018$ maupun gempa 7 SR pada 5/8/2018. Hasil sementara hitung cepat kerusakan dan kerugian akibat gempa di NTB mencapai lebih dari 5,04 trilyun rupiah. Angka ini sementara, hanya berdasarkan basis data pada 9/8/2018. Dipastikan dampak ekonomi lebih dari 5,04 trilyun nantinya. Kerusakan dan kerugian lebih dari 5,04 trilyun rupiah tersebut berasal dari sektor permukiman 3,82 trilyun rupiah, infrastruktur 7,5 milyar rupiah, ekonomi produktif 432,7 milyar rupiah, sosial budaya 716,5 milyar rupiah, dan lintas sector 61,9 milyar rupiah. Kerusakan dan kerugian terbanyak adalah sector permukiman yang kenyataan puluhan ribu rumah penduduk rusak berat, bahkan banyak yang rata dengan tanah". (https://bnpb.go.id/dampak-gempa-lombok-436-orang)

Semua sektor kehidupan manusia terdampak oleh bencana alam ini. Namun penelitian ini berfokus pada program pemulihan ekonomi pasca gempa bumi. Sebab sektor ekonomi menjadi salah satu persoalan mendasar bagi kelangsungan hidup manusia. Pelaksanaan program pemulihan ekonomi pasca gempa bumi memerlukan kerjasama antar satuan kerja perangkat daerah di lingkungan pemerintah Kabupaten Lombok Utara. Oleh karena itu dibutuhkan sebuah komunikasi yang efektif antar satuan kerja sehingga pelaksanaan dan tujuan program yang telah dirumuskan dapat berlangsung optimal.Sedarmayanti (2018: 189) menyebutkan komunikasi efektif mensyaratkan adanya pendekatan faktual dan aktual, namun sebelumnya perlu penguasaan dan pemahaman komunikasi yang benar secara komprehensif yang berlandaskan kejujuran komunikasi dan berkomunikasi atas dasar hati nurani, antara lain menerapkan " $4 \mathrm{C}$ ", yakni completeness, claryteness, correctness, dan consiceness.

Penyelenggaraan pemerintahan seringkali terjadi miskomunikasi dan proses koordinasi yang tidak efektif antar lembaga, munculnya ego sektoral di setiap lembaga terkait dengan pengambilan kebijakan publik, dan adanya disharmoni di antara lembaga-lembaga pemerintahan daerah. Problematika tersebut tidak menutup kemungkinan dapat terjadi dalam proses komunikasi di lingkungan pemerintahan Kabupaten Lombok Utara, yang dapat berdampak terhadap implementasi program pemulihan pembangunan pasca gempa bumi. Oleh karenanya penting mengetahui bagaimana komunikasi di lingkungan pemerintah 
Kabupaten Lombok Utara dalam pemulihan pembangunan ekonomi pasca gempa. Penelitian ini diharapkan mampu menjadi rujukan dalam pelaksanaan komunikasi pemerintahan yang efektif dan efisien khususnya ketika berada dalam situasi krisis. Dengan temuan formulasi sistem komunikasi pemerintahan yang efektif maka implementasi kebijakan pemerintah daerah dapat berlangsung secara optimal.

Penelitian tentang komunikasi pemerintah daerah dan bencana alam telah dilakukan oleh S Bekti Istiyanto dengan judul Komunikasi Pemerintah Daerah Dalam Program Pembangunan Kembali Daerah Wisata Pantai Pasca Bencana (Studi Komparatif Komunikasi Pembangunan Pemda Kabupaten Ciamis Jawa Barat, Pemda Kabupaten Cilacap Jawa Tengah dan Pemda Kabupaten Bantul DIY). Hasil penelitian ini menyebutkan bahwa:

1. Terdapat perbedaan-perbedaan yang cukup mendasar atas sikap pemerintah daerah khususnya dalam pelibatan masyarakat dalam proses komunikasi pembangunan terkait dengan penyikapan menangani bencana yang melanda kawasan wisata pantai di daerahnya. Komunikasi Pembangunan Pemda Ciamis dalam menangani pemulihan lokasi wisata Pantai Pangandaran Ciamis telah berhasil menyusun program pemulihan ekonomi masyarakat dan melibatkan mereka dalam tahap perencanaan meskipun tidak terlibat lagi dalam tahap pelaksanaan dan evaluasinya, sangat berbeda dengan yang terjadi di lokasi wisata Pantai Widarapayung Cilacap dan Pantai Parang Tritis Bantul. Di Pantai Widarapayung sama sekali tidak terdapat program terpadu yang membuat lokasi wisata dan kehidupan perekonomian masyarakat menjadi lebih baik dibandingkan sebelumnya. Bahkan karena tiadanya komunikasi yang terjadi antara pemda setempat atas program pembangunan yang jelas menjadikan kegiatan kepariwisitaan di lokasi ini berjalan di tempat. Sementara program yang dilaksanakan pemda Bantul di Pantai Parang Tritis merupakan ide lama yang telah ada sebelum terjadi bencana. Namun kemudian dengan terjadinya bencana gempa pembangunan relokasi kegiatan usaha bagi masyarakat seolaholah mendapatkan pemicu dan momentum untuk melaksanakannya. Keberhasilan relokasi kegiatan usaha ini didukung adanya komunikasi pembangunan yang memadai dari pemda kepada masyarakat sekitar lokasi wisata.

2. Tingkat partisipasi masyarakat dalam program komunikasi pembangunan yang terjadi sangat berbeda di tiga lokasi yang diteliti. Kesemuanya sangat tergantung dari inisiatif masing-masing pemerintah daerah dalam melakukan komunikasi pembangunan terhadap masyarakatnya. Bila di Pantai Pangandaran, masyarakat dilibatkan di awal perencanaan program dan program yang disusun dilaksanakan oleh pemerintah. Maka sangat berbeda dengan yang terjadi di lokasi wisata Pantai Widarapayung. Karena tidak ada program pemulihan atau penataan ekonomi masyarakat kawasan pantai dari pemerintah daerah maka pelibatan partisipasi masayarakat menjadi mandiri dan tidak bergantung dengan bantuan pemerintah. Muncul kelompok mandiri masyarakat yaitu SIBAT yang peduli adanya bencana di kawasan wisata tempat mereka tinggal dan hidup serta berjalan tanpa proses komunikasi yang intens dengan pemerintah daerahnya. Sementara untuk masyarakat Pantai Parang Tritis sudah dalam tahap menerima karena program ini telah 
direncanakan pemda Bantul dua tahun sebelum dilaksanakan dan menjadi pemicu dengan terjadinya bencana gempa yang melanda Kabupaten Bantul dan sekitarnya.

\section{Komunikasi Organisasi Pemerintahan}

Penelitian ini mengkaji bagaimana komunikasi antar satuan kerja perangkat daerah Lombok Utara dalam pembangunan ekonomi pasca gempa bumi. R. Wayne Pace dan Don F. Faules (2001) mendefiniskan komunikasi organisasi menjadi dua, yakni definisi fungsional dan definisi interpretif. Definisi fungsional komunikasi organisasi adalah sebagai pertunjukan dan penafsiran pesan di antara unit-unit komunikasi yang merupakan bagian dari suatu organisasi tertentu. Suatu organisasi terdiri dari unit-unit komunikasi dalam hubungan-hubungan hierarkis antara yang satu dengan lainnya dan berfungsi dalam suatu lingkungan. Sementara, definisi interpretif komunikasi organisasi adalah proses penciptaan makna atas interaksi yang merupakan organisasi. Proses interaksi tersebut tidak mencerminkan organisasi; ia adalah organisasi. Komunikasi organisasi adalah "perilaku pengorganisasian" yang terjadi dan bagaimana mereka yang terlibat dalam proses itu bertransaksi dan memberi makna atas apa yang sedang terjadi (Pace dan Faules, 2001: 31-33).

Redding dan Sanborn mendefinisikan komunikasi organisasi adalah pengiriman dan penerimaan informasi dalam organisasi yang kompleks. Yang termasuk dalam bidang ini adalah komunikasi internal, hubungan manusia, hubungan persatuan pengelola, komunikasi downward atau komunikasi dari atasan kepada bawahan, komunikasi upward atau komunikasi dari bawahan kepada atasan, komunikasi horizontal atau komunikasi dari orang-orang yang sama level/tingkatnya dalam organisasi, keterampilan berkomunikasi dan berbicara, mendengarkan, menulis dan komunikasi evaluasi program (Muhammad, 2005: 65).

Joseph A. Devito mendefinisikan komunikasi organisasi merupakan pengiriman dan penerimaan berbagai pesan di dalam organisasi - di dalam kelompok formal maupun informal organisasi. Komunikasi formal adalah komunikasi yang disetujui oleh organisasi itu sendiri dan sifatnya berorientasi pada organisasi. Isinya berupa cara-cara kerja di dalam organisasi, produktifitas, dan berbagai pekerjaan yang harus dilakukan dalam organisasi: memo, kebijakan, pernyataan, jumpa pers, dan surat-surat resmi. Komunikasi informal adalah komunikasi yang disetujui secara sosial. Orientasinya tidak pada organisasinya sendiri, tetapi lebih pada para anggotanya secara individual (Devito, 1997: 340).

Komunikasi pemerintahan merupakan komunikasi antar manusia (human communication) yang terjadi dalam konteks organisasi pemerintahan. Karena itu komunikasi pemerintahan tidak lepas dari konteks komunikasi organisasi dan ia juga merupakan bagian dari komunikasi organisasi. Arus penyampaian dan penerimaan pesan dilakukan melalui jaringan yang sifat hubungannya saling tergantung satu sama lain berdasarkan aturan-aturan formal. Pesan yang disampaikan dan yang diterima bukan saja berupa informasi, melainkan juga penyebaran ide-ide (sharing ideas), instruksi (instruction), atau perasaan-perasaan (feelings) berhubungan dengan tindakan dan kebijakan pemerintah. Melalui komunikasi 
pemerintahan, birokrat pemerintah berbagi informasi, gagasan atau perasaan, dan sikap dengan partisipan komunikasi lainnya yang disebut komunikan, yaitu aparatur pemerintah untuk internal organisasi dan dunia usaha, masyarakat dan organisasi-organisasi nonpemerintah untuk eksternal organisasi, dan sebaliknya (Silalahi, 2004: 36).

Komunikasi pemerintahan pada hakekatnya merupakan proses penyebaran dan pertukaran informasi di dalam dan dengan luar organisasi. Melalui komunikasi pemerintahan, maka eksekutif pemerintahan bertukar dan membagi informasi dengan yang lain, yaitu dengan legislatif, dengan staf, dengan pelaku bisnis, dan dengan masyarakat. Melalui komunikasi, eksekutif pemerintah atau administrator atau manajer pemerintah bermaksud untuk mempengaruhi sikap (attitude), pemahaman (understanding), dan perilaku (behavior) birokrasi dan masyarakat. Dengan demikian, tiap orang yang terlibat dalam penyelenggaraan pemerintahan demokratis merupakan bagian dari proses komunikasi pemerintahan, baik sebagai sender di satu waktu, dan di waktu lain ia menjadi receiver.

Komunikasi pemerintahan tidak saja sebagai sarana atau alat bagi pemerintah untuk menyampaikan dan atau menerima informasi tentang suatu kebijakan publik, misalnya, tetapi juga sebagai sarana memadukan kegiatan-kegiatan secara terorganisasi dalam mewujudkan kerjasama. Juga merupakan sarana penyaluran masukan sosial ke dalam sistem sosial, dan sarana memodifikasi perilaku, mempengaruhi perubahan, memproduktifkan informasi, sarana untuk mencapai tujuan serta membantu pelaksanaan dan memadukan fungsi-fungsi manajemen. Adapun fungsi komunikasi dalam suatu organisasi, termasuk organisasi pemerintah sebagai organisasi nonprofit adalah: fungsi informatif, regulatif, persuasif, dan integratif. Fungsi informatif berarti, komunikasi dipandang sebagai suatu sistem pemrosesan informasi dan kemudian menyebarkannya kepada pihak yang membutuhkan, baik internal maupun eksternal. Fungsi regulatif, berkaitan dengan peraturan-peraturan yang berlaku dalam suatu organisasi. Regulasi dibuat melalui proses komunikasi oleh orang-orang yang berada dalam posisi otoritas pembuat regulasi. Fungsi persuasif dimaksudkan sebagai suatu cara melalui komunikasi dilakukan persuasi kepada orang lain sehingga mereka menerima pesan dan melaksanakannya dengan cara sukarela, tanpa paksaan atau dipaksa (Silalahi, 2004: 3940).

Hambatan komunikasi merupakan salah satu masalah penting dari sekian banyak problematika dalam sistem komunikasi organisasi pemerintahan. Komunikasi dalam organisasi tidak selamanya berjalan lancar sebagaimana yang diharapkan. Robbins menguraikan beberapa hambatan komunikasi:

1. Penyaringan (filtering); berupa komunikasi yang dimanipulasi oleh si pengirim sehingga nampak lebih bersifat menyenangkan si penerima. Komunikasi semacam ini dapat berakibat buruk bagi organisasi, karena jika informasinya dijadikan dasar pengambilan keputusan, maka keputusan yang kelak akan dihasilkan berkualitas rendah dan salah.

2. Persepsi selektif; keadaan dimana penerima pesan di dalam proses komunikasi melihat dan mendengar atas dasar keperluan, motivasi, latar belakag pengalaman, dan ciri-ciri pribadi 
lainnya. Pengalaman, pendidikan, pengetahuan, dan budaya akan ikut menentuka cara menafsirkan pesan. Sehingga persepsi yang demikian akan menjadi penghambat bagi komunikasi yang efektif.

3. Perasaan; hambatan ini berupa perasaan penerima saat menerima pesan komunikasi akan mempengaruhi caranya menginterpretasikan pesan.

4. Bahasa; kata-kata memiliki makna yang berbeda antara seseorang dengan orang lain. Terkadang arti sebuah kata tidak berada pada kata itu sendiri tetapi pada kita. Umur, pedidikan, lingkungan kerja dan budaya adalah faktor-faktor yang dapat mempengaruhi bahasa yang digunakan seseorang atau definsi yang dilekatkan pada suatu kata.

Arni Muhammad menuliskan secara prinsip ada dua hambatan komunikasi organisasi, yaitu faktor personal dan faktor organisasi. Dua faktor tersebut akan diuraikan sebagai berikut:

1. Faktor personal; menekankan pada aspek manusia yang mempersepsi pesan yang diterimanya. Hal-hal yang berkenaan dengan persepsi yang ikut mempengaruhi proses komunikasi adalah a).orang mengamati sesuatu secara seleksi; b). orang melihat sesuatu konsisten dengan apa yang mereka punyai; c). bahasa itu sendiri kadang-kadang kurang tepat; d). arti suatu pesan terjadi pada level isi dan hubungan; e). distorsi diperkuat oleh tidak adanya konsistensi bahasa verbal dan nonverbal; f). pesan yang meragukan sering mengarahkan pada gangguan; g). kecenderungan memori kearah penajaman dan penyamarataan detail; h). motivasi mungkin membangkitkan distorsi pesan.

2. Faktor organisasi; hal-hal yang turut memberi kontribusi terhadap distorsi pesan dalam komunikasi, yaitu: a). kedudukan atau posisi dalam organisasi; b). hirarki dalam organisasi; c). keterbatasan berkomunikasi; d). hubungan yang tidak personal; e). sistem aturan dan kebijaksanaan; f). spesialisasi tugas; g). ketidakpedulian pimpinan; h). prestise; i). jaringan komunikasi

Agar komunikasi dapat berjalan efektif maka hambatan-hambatan komunikasi di atas harus dapat diminimalisir. Down menguraikan beberapa cara yang dapat ditempuh untuk mengurangi hambatan dalam proses komunikasi organisasi pemerintahan (Muhammad, 2005: 207-222):

1. Menetapkan lebih dari satu saluran komunikasi, dapat ditempuh dengan: a). menggunakan sumber informasi yang di luar organisasi; b). menciptakan bidang tanggung jawab yang tumpang tindih diantara karyawan sehingga adanya kompetisi dalam proses komunikasi.

2. Menciptakan prosedur untuk mengimbangi distorsi atau hambatan, yaitu dengan mengidentifikasi berbagai gangguan secara teliti sehingga dapat diperoleh informasi secara tepat.

3. Menghilangkan pengantara antara pembuat keputusan dengan pemberi informasi, yaitu dengan membuat struktur organisasi yang mendatar. Dengan mengurangi jumlah mata rantai jaringan komunikasi maka jumlah penyaringan dan distorsi komunikasi akan berkurang. 
4. Mengembangkan pembuktian gangguan pesan, dengan menciptakan sistem pesan yang tidak boleh mengubah arti pesan selama dalam pengiriman. Untuk membuktikan tidak ada distorsi, suatu pesan harus dapat dikirimkan tanpa penyingkatan atau perluasan diantara sumber dan tujuan si penerima.

\section{Manajemen Recovery Pembangunan Ekonomi Pasca Bencana}

Merujuk pada Peraturan Kepala Badan Nasioonal Penanggulangan Bencana nomor 11 Tahun 2008 tentang Pedoman Rehabilitasi dan Rekonstruksi Pasca Gempa, yang dimaksud dengan pemulihan sosial ekonomi budaya adalah upaya untuk memfungsikan kembali kegiatandan/atau lembaga sosial, ekonomi dan budaya masyarakat didaerah bencana. Kegiatan pemulihan sosial, ekonomi, dan budaya ditujukan untuk menghidupkan kembali kegiatan dan lembaga sosial,ekonomi dan budaya masyarakat di daerah bencana sepertisebelum terjadi bencana.

Prosedur/Persyaratan Teknis Perencanaan dan Persyaratan Teknis Pemulihan Sosial, Ekonomidan Budaya. Setiap kegiatan pemulihan sosial, ekonomi dan budaya sebagaimana dijelaskan di atas harus diawali dengan penyusunan rencana teknis rinci pemulihan sosial, ekonomidan budaya yang setidak-tidaknya mencakup aspek-aspek:1) kegiatan dan lembaga sosial, ekonomi dan budaya yangmenjadi sasaran; 2) permasalahan yang dihadapi;3) sumberdaya yang tersedia; 4) skenario, mekanisme danteknis pelaksanaanya; 5) rencana pembiayaan; dan6) penyelenggara.Penyusunan rencana teknis pemulihan sosial, ekonomi danbudaya dilakukan oleh BPBD dibantu oleh lembaga/dinas/instansi yang relevan.

Mekanisme dan teknis pelaksanaan pemulihan sosial, ekonomidan budaya harus mempertimbangkan karakter, kondisi dansituasi masyarakat yang menjadi korban bencana sertamengacu pada ketentuan-ketentuan lain yang relevan dantelah ditetapkan oleh dinas/instansi yang mempunyaikewenangan untuk itu.

\section{Metode}

Metode penelitian yang digunakan adalah deskriptif kualitatif. Metode kualitatif sebagai suatu prosedur penelitian menghasilkan data deskriptif berupa kata-kata tertulis ataupun lisan dari orang-orang dan perilaku yang diamati. Data diperoleh melalui wawancara mendalam (Indepth Interview), pengamatan (observasi) dan dokumentasi. Proses analisis data dimulai dengan mempelajari data yang tersedia dari berbagai sumber atau dokumen yang berkaitan.

Penelitian ini dilakukan di Satuan Kerja Perangkat Daerah (SKPD) Kabupaten Lombok Utara yang meliputi: Dinas Koperasi UMKM Perindag, Dinas Sosial, Dinas Pertanian, Dinas Pariwisata, serta Dinas PU. Subjek penelitian dan sekaligus menjadi Informan dipilih dari level pengambil kebijakan pada satuan kerja perangkat daerah Lombok Utara yang bertanggung jawab terhadap pembangunan ekonomi. Sementara obyek penelitian difokuskan pada komunikasi pembangunan yang dilakukan oleh Satuan Kerja Perangkat Daerah (SKPD) di 
Kabupaten Lombok Utara yang terkait dengan pemulihan pembangunan ekonomi pasca gempa bumi tahun 2018

\section{Hasil dan Pembahasan}

Peristiwa gempa bumi pada 5 Agustus 2018 yang melanda Nusa Tenggara Barat, berdampak signifikan di Kabupaten Lombok Utara. Kerusakan dan kerugian yang disebabkan oleh bencana alam tersebut membuat pemerintah daerah harus bekerja ekstra untuk memulai kembali dari awal program percepatan pembangunan ekonomi yang telah dicanangkan sejak tahun 2016. Pelaksanaan program pemulihan ekonomi pasca gempa bumi memerlukan kerjasama antar satuan kerja perangkat daerah di lingkungan pemerintah Kabupaten Lombok Utara. Oleh karena itu dibutuhkan koordinasi yang baik antar satuan kerja sehingga pelaksanaan dan tujuan program yang telah dirumuskan dapat berlangsung optimal.

Implementasi program pemulihan ekonomi pasca gempa bumi merujuk pada Peraturan Kepala Badan Nasional Penanggulangan Bencana nomor 11 Tahun 2008 tentang Pedoman Rehabilitasi dan Rekonstruksi Pasca Gempa, yang dimaksud dengan pemulihan sosial ekonomi budaya adalah upaya untuk memfungsikan kembali kegiatan dan/atau lembaga sosial, ekonomi dan budaya masyarakat di daerah bencana. Kegiatan pemulihan sosial, ekonomi, dan budaya ditujukan untuk menghidupkan kembali kegiatan dan lembaga sosial, ekonomi dan budaya masyarakat di daerah bencana seperti sebelum terjadi bencana.

Setiap kegiatan pemulihan sosial, ekonomi dan budaya sebagaimana dijelaskan di atas harus diawali dengan penyusunan rencana teknis pemulihan sosial, ekonomi dan budaya yang setidak-tidaknya mencakup aspek-aspek:1) kegiatan dan lembaga sosial, ekonomi dan budaya yang menjadi sasaran; 2) permasalahan yang dihadapi; 3) sumberdaya yang tersedia; 4) skenario, mekanisme dan teknis pelaksanaanya; 5) rencana pembiayaan; dan 6) penyelenggara. Penyusunan rencana teknis pemulihan sosial, ekonomi dan budaya dilakukan oleh BPBD dibantu oleh lembaga/dinas/instansi yang relevan.

Berdasarkan pedoman pelaksanaan program tersebut terlihat bahwa koordinasi antar instansi menjadi kunci keberhasilan implementasi program pemulihan ekonomi pasca gempa bumi. Koordinasi merupakan salah satu fungsi manajemen, sebab koordinasi adalah fungsi yang menghubungkan fungsi-fungsi manajemen lainnya. Koordinasi berarti mengikat, mempersatukan dan menyelaraskan semua aktivitas dan usaha. Dalam konteks ini adalah koordinasi antar satuan kerja perangkat daerah di Kabupaten Lombok Utara dalam merumuskan ataupun melaksanakan kebijakan terkait dengan program pemulihan pembangunan ekonomi pasca gempa bumi 2018.

Pembangunan ekonomi di Kabupaten Lombok Utara dibawah tanggung jawab lima dinas dan dua bidang di lingkungan pemerintah daerah, yaitu Dinas Kebudayaan dan Pariwisata; Dinas Sosial, Pemberdayaan Perempuan dan Perlindungan Anak; Dinas Pekerjaan Umum dan Penataan Ruang; Dinas Koperasi, UKM, Perindustrian dan Perdagangan; Dinas Ketahanan Pangan dan Pertanian; Bagian Perekonomian Sekretariat daerah; serta Bidang Ekonomi Badan Perencanaan Pembangunan Daerah.

Kebijakan recovery pasca gempa di Kabupaten Lombok Utara dirumuskan dalam Dokumen Rehabilitasi dan Rekonstruksi (Dokumen RR), yang dibuat oleh pemerintah 
Kabupaten Lombok Utara, difasilitasi oleh Badan Nasional Penanggulangan Bencana (BNPB). Dokumen RR diproduksi oleh Badan Penanggulangan Bencana Daerah (BPBD) dan Badan Perencanaan Pembangunan Daerah (Bappeda). Ditingkat kabupaten dilakukan oleh BPBD, dengan seluruh Satuan Kerja Perangkat Daerah (SKPD) di lingkup pemerintah Kabupaten Lombok Utara, bersinergi dengan Bappeda. Moch Wahyu Darmawan (Kepala Bagian Perekonomian Sekretariat daerah) mengungkapkan terkait dengan recovery pasca gempa terdapat empat domain: infrastruktur (perumahan), infrastruktur (jalan, jembatan, pelabuhan), perekonomian (produksi, distribusi), dan bidang lainnya (sarana kebudayaan, pariwisata).

Upaya yang dilakukan oleh pemerintah kabupaten Lombok Utara dalam rangka percepatan recovery bidang ekonomi pasca bencana, sebagaimana yang diungkapkan oleh Moch Wahyu Darmawan (Kepala Bagian Perekonomian Setda), meliputi: 1). Pendataan, yang meliputi: Pendataan sarana prasarana perekonomian yang rusak, Pendataan pelaku yang terdampak misalnya hotel, restoran, UMKM, kelompok tani, nelayan, dan Pendataan omset usaha; 2). Kajian-kajian melalui focus group discussion (FGD) pasca bencana, meliputi: Dorongan-dorongan terhadap produk unggulan daerah, seperti produk dari kelapa, kopi, coklat, Memantapkan dokumen-dokumen perencanaan (regulasi) pembangunan ekonomi seperti penyusunan Rencana Induk Pariwisata Daerah (RIPDA), Mempercepat pembentukan Badan Usaha Milik Daerah (BUMD), Mempertahankan inflansi ke titik yang normal.

Upaya yang diuraikan di atas sejalan dengan pernyataan yang diberikan oleh Andi (mitra Bidang Ekonomi Bappeda) mengatakan bahwa kunci dari komunikasi dalam program percepatan pemulihan ekonomi pasca gempa meliputi dua hal, yaitu: 1). Penguatan komunikasi antar kelembagaan. Ditingkat kelembagaan memahami tugas pokok dan fungsi maka akan banyak menyelesaikan persoalan; 2). Penguatan di tingkat regulasi, dan asistensinya. Regulasi tersusun jelas sehingga aturan main jelas. Maka komunikasi antara kabupaten, dengan pihak kecamatan dan desa menjadi jelas.

Berdasarkan uraian di atas, kunci keberhasilan percepatan pembangunan ekonomi pasca gempa adalah koordinasi antar satuan kerja perangkat daerah. Mekanisme pengkoordinasian dasar dalam organisasi terdiri dari: pertama, hierarki manajerial, yaitu rantai perintah, aliran informasi dan kerja, wewenang formal, hubungan tanggung jawab dan akuntabilitas jelas, menumbuhkan integrasi bila dirumuskan jelas dan tepat, dilaksanakan dengan pengarahan tepat; kedua, aturan dan prosedur, yaitu manajerial untuk menangani kejadian rutin, sehingga peralatan efisien untuk koordinasi dan pengawasan rutin; ketiga, rencana dan penetapan tujuan, yaitu untuk pengkoordinasian melalui pengarahan seluruh satuan organisasi terhadap sasaran yang sama (Sedarmayanti, 2018).

Prosedur dan proses komunikasi dalam perumusan kebijakan di lingkungan pemerintah daerah Lombok Utara dilakukan melalui saluran-saluran formal rutin, sebagaimana yang dikemukakan oleh Hasto (Kepala Bidang Ekonomi Bappeda) bahwa terkait dengan penganggaran dalam percepatan ekonomi, Bappeda bekerjasama dengan mitra dan pelaku (praktisi) diskusi secara kontinu didalam perannya melalui Kebijakan Umum Anggaran dan Prioritas Platfon Aanggaran Sementara (KUA PPAS) berdasarkan prioritas dan kebutuhan yang 
terpenting bukan keinginan dibuat Rencana Kerja dan Anggaran (RKA), selain itu juga melalui forum Musyawarah Perencanaan Pembangunan (musrembang) desa, kecamatan, kabupaten dan Bappeda membuat perencanaan. Ada desk sesuai kapasitas masing-masing diusulkan ke tim anggaran Dewan Perwakilan Rakyat Daerah (DPRD).

Proses komunikasi yang berjalan dari bawah ke atas melalui saluran-saluran formal tersebut, sejalan dengan yang diungkapkan Moch Wahyu Darmawan (Kepala Bagian Perekonomian Setda), menurutnya, aliran informasi dalam perumusan kebijakan recovery pasca bencana selain bersumber dari masyarakat, juga berdasarkan pada kebijakan dari pemerintah pusat (topdown), misal dalam pengendalian inflansi daerah berdasarkan peraturan presiden, jika dalam bidang kerjanya dalam melaksanakan tugas berdasarkan instruksi pimpinan dalam hal ini adalah sekretaris daerah (sekda).

Program percepatan pembangunan ekonomi pasca gempa bumi agar berjalan efektif dan efisien dibutuhkan koordinasi perencanaan, yaitu arus informasi dan proses komunikasi antar dan antara lembaga perencanaan dengan pemangku kepentingan, baik secara vertikal, horizontal, maupun lintas horizontal-vertikal. Berdasarkan data yang diperoleh maka dalam proses koordinasi pemerintah Kabupaten Lombok Utara menjalankan dua tipe koordinasi, yaitu: pertama, koordinasi vertikal yaitu pengarahan yang dilakukan oleh atasan kepada bawahan (downward) ataupun bawahan kepada atasan (upward), dalam hal ini adalah unit atau satuan kerja yang ada di bawah wewenangnya dan tanggung jawabnya; kedua, koordinasi horizontal yaitu koordinasi kegiatan antar unit atau satuan kerja yang setingkat.

Arus komunikasi dari atas ke bawah (downward communication) berfungsi untuk penyampaian instruksi kerja, penjelasan alasan suatu tugas harus dilakukan, penyampaian informasi tentang peraturan-peraturan yang berlaku, serta pemberian motivasi kepada karyawan agar bekerja lebih baik. Arus komunikasi dari bawah ke atas (upward communication) berfungsi untuk penyampaian informasi tentang pekerjaan yang telah dilaksanakan, penyampaian informasi tentang permasalahan-permasalahan pekerjaan yang tidak dapat diselesaikan di tingkat bawahan, penyampaian saran-saran perbaikan dari bawahan, serta penyampaian keluhan dari bawahan baik tentang masalah pribadi maupun pekerjaan. Sementara, komunikasi horizontal berfungsi untuk memperbaiki koordinasi tugas, upaya pemecahan masalah, saling berbagi informasi, upaya pemecahan konflik dan membina hubungan melalui kegiatan bersama.

Koordinasi berperan penting dalam kegiatan organisasi, peran tersebut adalah: mencegah terjadinya kekacauan, percekcokan, dan kekembaran atau kekosongan pekerjaan; agar pegawai dan pekerjaannya diselaraskan serta diarahkan untuk mencapai tujuan organisasi; dapat memanfaatkan sarana dan prasarana dalam pencapaian tujuan; agar semua unsur manajemen dan pekerjaan masing-masing individu pegawai harus membantu tercapainya tujuan organisasi, serta agar semua tugas, kegiatan dan pekerjaan terintegrasi kepada sasaran yang diinginkan.

Blockages atau rintangan dalam sistem komunikasi merupakan permasalahan serius dalam komunikasi pemerintahan, termasuk komunikasi di kabupaten Lombok Utara. Rintangan dalam sistem komunikasi pemerintah di kabupaten Lombok Utara disebabkan oleh status 
distance/perbedaan status yaitu rintangan yang berhubungan dengan perbedaan status sehingga lebih sulit dibandingkan dengan komunikasi antara dua orang dengan status yang sama. Dalam hal ini informasi bergerak ke atas atau ke bawah melalui berbagai level hierarkis dari suatu organisasi sehingga terjadi filtering dan distorting (Rachmat, 2018). Sebagaimana yang diungkapkan oleh Sukersih (Kasi Pengolahan, Pemasaran dan Pemasaran Dinas Ketahanan Pangan dan Pertanian) Jalur koordinasi gampang diucapkan namun sulit dilaksanakan, tetapi kita lewat bappeda difasilitasi kita adakan koordinasi dengan perindag mengenai gimana sih mengemas produk, tetapi mereka juga siap kalau memang mau adakan pelatihan mengenai kemasan segala macam mereka siap mendukung. Selama ini memang belum terjalin suatu koordinasi yang rutin, sudah terjalin namun belum rutin. Sudah terjalin dalam konteks difasilitasi oleh bappeda secara intens belum.

Rintangan selanjutnya disebabkan oleh frame of reference/pemberian penafsiran, yaitu berkaitan dengan pemberian penafsiran atau penerima komunikasi memiliki satu 'mental set' yang menghalangi persepsi kuat dari masalah, atau respons tidak sesuai dengan stimuli, sehingga persepsi informasi bervariasi di antara individu (Rachmat, 2018) sebagaimana pernyataan Syafruddin (Dinas sosial pembedayaan perempuan dan perlindungan anak) Kalaulah dinas sosial dipandang oleh teman-teman kabupaten ini tidak boleh menangani kube, dan sejenis itu regulasi yang jelas yang mengatakan tidak boleh itu mana, itu yang pertama. Yang kedua kenapa setiap tahun dinas sosial di seluruh Indonesia didorong untuk mengusulkan bansos-bansos yang berkaitan dengan kube, sarana lingkungan yang sifatnya fisik juga untuk kepentingan masyarakat. Kenapa daerah menjustifikasi dinas sosial tidak boleh menangani itu, padahal pusat sendiri sampai hari ini tetap aktif menyelenggarakan itu, makanya akan didiskusikan dengan orang-orang kementrian sosial sudut pandang apa yang digunakan sehingga daerah terkesan menihilkan peran itu.

\section{Simpulan}

Kabupaten Lombok Utara merupakan wilayah yang terdampak bencana gempa bumi pada tahun 2018 secara signifikan. Pemulihan pembangunan ekonomi pasca gempa bumi di Lombok Utara fokus pada infrastruktur (perumahan), infrastruktur (jalan, jembatan, pelabuhan), perekonomian (produksi, distribusi), dan bidang lainnya (sarana kebudayaan, pariwisata). Namun, dalam pelaksanaannya terdapat hambatan komunikasi antar dinas terkait yang disebabkan oleh perbedaan status dan pemberian penafsiran yang berbeda atas regulasi dan kebijakan. Sehingga memunculkan fenomena ego sektoral dalam praktik komunikasi organisasi di pemerintah daerah kabupaten Lombok utara. hal tersebut diprediksi akan menjadi penghambat percepatan pembangunan ekonomi pasca bencana gempa bumi, sebab pelaksanaan program pemulihan ekonomi pasca bencana memerlukan kerjasama antar satuan kerja perangkat daerah di lingkungan pemerintah Kabupaten Lombok Utara. Oleh karena itu, dibutuhkan koordinasi yang efektif antar satuan kerja perangkat daerah sehingga pelaksanaan dan tujuan program yang telah dirumuskan dapat berlangsung optimal. 


\section{Daftar Pustaka}

Devito, J. A. (1997). Komunikasi Antarmanusia: Kuliah Dasar. Edisi ke lima. Penerjemah Agus Maulana, Professional Books, Jakarta.

Masmuh, A. (2010), Komunikasi Organisasi dalam Perspektif Teori dan Praktik, UMM Press, Malang.

Muhammad, A. (2005). Komunikasi Organisasi, Bumi Aksara, Jakarta.

Pace, R. W. \& Don F. Faules. (2001). Komunikasi Organisasi: Strategi Meningkatkan Kinerja Perusahaan, Remaja Rosdakarya, Bandung.

Rachmat. (2018). Dasar-dasar Manajemen Pemerintahan, Pustaka Setia, Bandug.

Sedarmayanti. (2018). Komunikasi Pemerintahan, Refika, Bandung.

Silalahi, U. (2004). Komunikasi Pemerintahan: Mengirim dan Menerima Informasi Tugas dan Informasi Publik, Jurnal Administrasi Publik, Vol 3, No 1, April 2004.

Peraturan Kepala Badan Nasional Penanggulangan Bencana nomor 11 Tahun 2008 tentang Pedoman Rehabilitasi dan Rekonstruksi Pasca Gempa. 